\title{
Creating a Global Cultural Consciousness in a Japanese EFL Classroom
}

\author{
Scott Aubrey \\ Tel: 81-90-9821-6286 E-mail: scottaubrey@hotmail.com
}

\begin{abstract}
Recently, culture has taken an important role in language education. In this view, creating a global cultural consciousness among second language (L2) students can help bridge the gap between linguistic ability and functional intercultural communication. This paper, which makes reference to Japanese adult EFL learners, justifies the body of opinion that creating a global cultural consciousness in the EFL classroom can eventually yield solutions to Japan's communication weaknesses. The first half of this paper illustrates the language-culture connection and its consequences for Japan in a globalizing world. I explain how, in the context of Japan, there is a need to create a cultural awareness in order to implement the ideal Japanese educational philosophy. In the second half of this paper, a five-day lesson plan using an ethnographic teaching methodology is outlined. A discussion of the formation of a new cultural identity for Japanese EFL students and its implications will conclude this paper.
\end{abstract}

Keywords: Globalization, Japanese students, Ethnography, Global cultural consciousness, Intercultural communication, pedagogy

\section{Introduction}

"Learning to speak a foreign language is a formidable task, and most adults fail to achieve fluency even after many years of trying" (Salzmann, 1993, p. 46). Traditional forms of teaching EFL in Japan have focused on grammar and translation techniques, which have yielded little benefit to a student's communicative ability (Mantero and Iwai, 2005). Critchley (1998) writes that the average Japanese university student is conditioned to pay "exceptional attention to the grammatical form - often at the expense of meaning". This focus on form over fluency has led to the Japanese government implementing an increasingly more communicative approach to learning English in high schools (Riley, 2008). The gap between grammar competency and fluency in English is of great concern in Japan. As English rises to the heights of world language status never seen before in history, countries that fail to educate their citizens accordingly are losing out on a variety on platforms. The first part of this paper examines how culture can fill the gap in terms of giving students a context in which they can express themselves; furthermore, an awareness of culture can also facilitate the transformation of the Japanese cultural identity into a more globally conscious one.

\section{Theory of the Language-Culture Connection and the Japanese Context}

\subsection{Linking Culture and Language}

Luis Kelly (1969) wrote that "the culture orientation of language teaching has always been one of its unstated claims" (p. 378). In this first section, I will begin by outlining the fundamental concept of linking culture to language. This forms the basis in which language learning can be transformed into a more effective experience. Raising the status of culture from simply a result of language learning to an overt part of language teaching curriculum is a change, I believe, that will ultimately give way to a better method of preparing students for communicating in a global environment. .

Although culture has been notoriously difficult for scholars to define, an appropriate definition is that culture stands for "creative endeavors that constitute the intellectual and aesthetic life of a community, and the beliefs, customs, and values that govern the practice of everyday life" (Kumaravadivelu, 2008, p. 10). Culture, in this sense, is used by societies to evaluate their behavior and form unified communities. Through language, members can refine their ideas and develop their cultural identity.

Many academics have proposed strong connections between the language and culture of a society, but none have had such an impact as the Sapir-Whorf hypothesis. Benjamin Lee Whorf (1956) stated that, "The background linguistic system of each language is not merely a reproducing instrument for voicing ideas but rather is itself the shaper of ideas" (p. 213). He then went further to conclude that "users of markedly different grammars are pointed by their grammars toward different types of observations... and hence are not equivalent as observers but must arrive at somewhat different views of the world" (p. 221).

Whorf's idea that a language directly affects the thought process is referred to as language determinism. Although this theory has been thought of as an exaggeration by most academics, subsequent updates to his theory have kept similar 
basic principles (Kumaravadivelu, 2008, p. 20). Applied linguist Jim Gee (1993) offered a compromise to the Whorfian theory:

"The way language cuts up the world will influence how we initially think about something, but it does not determine how we finish thinking about it. Under pressure we can think about things outside the categories of our language, because we find other people's ways of doing things senseful. We find them senseful because, at least where language is concerned, they are all chosen from the inventory of ways allowed by the human brain, which is, like the eye, everywhere the same across cultures." (p. 11)

Another linguist, Anna Wierzbicka (1997), acknowledged that Whorf's theory had a great deal of exaggeration, but that "clearly...the outlook of a society is...influenced by its language" (p. 5). For the purpose of this paper I will adopt a mix of these theories - a 'soft' version of language determinism: it is possible for people to think outside their language-reality, yet perspectives of thought are still heavily influenced by their language.

\subsection{Language Determinism and the Japanese Language}

Turning to the context of Japan, Senko K. Maynard, in his book Expressive Japanese (2005), outlines various characteristics of the Japanese language that are particularly unique and alter the behavior of Japanese social interactions. Two examples of these are given below:

Social Territory. The style and manner in which one expresses emotion and empathy often depend on awareness of social territory. Speakers outside the uchi (group) are soto persons. There are two consequences of this: 1) formality increases outside of a group, and 2) the contexts of most sentences are implied, leaving the burden of the meaning on the listener, not the speaker. (Maynard, 2005, pp. 41-42)

Tatemae and Honne. Japanese speakers are known to distinguish between tatemae (principles, public face) and honne (true private thoughts and feelings). For speakers of the Japanese language, it is important to maintain tatemae in many public situations, but it is equally important to express honne to people who share intimacy and social territory. (Maynard, 2005, p. 43)

It goes without saying that these language characteristics are quite different from their 'western counterparts', as are the cultural behaviors that are linked to them. Maynard goes on to write:

There is a gap between what one language/culture may find reasonable and what the other language/culture may not... Japanese emotions, therefore, are in many ways particular to Japanese language, culture, and society.... Part of learning a foreign language is discovering different feelings in our hearts. To experience different feelings is to discover different senses of self within ourselves. (p.12)

The consequences of this in the language classroom can be clearly explained through a hypothetical example. Assuming that a Japanese language teacher, who is a native speaker of Japanese, is teaching a non-Japanese student in Canada, the L2 student of Japanese will also become a student of tatamae, honne, uchi, and soto, and will "discover different (Japanese) feelings." Therefore, the same student will at some point be challenged to express these Japanese feelings in their native language and act out these feelings in their native culture. Through language, the student is essentially borrowing unique features of the teacher's own native culture and using it in his/her native culture. Not only does language influence culture, but culture influences language, which then influences other cultures. A language student's native culture $(\mathrm{C} 1)$, therefore, is influenced by the teacher's native culture $(\mathrm{C} 2)$, and is transformed into a hybrid culture (C3), which is far more culturally intuitive. The same applies for EFL students in Japan learning from native English speakers (this is the case in the Japanese private language industry). This concept of adopting different language-realities to create a $\mathrm{C} 3$ identity has profound implications.

Sociolinguist, Joshua Fishman (1980), explained the moral implications of this clearly: "the world will be a better place and humanity will be more successful in solving its ever more serious problems if we all master more (and more dissimilar) languages, because of them we can share perspectives and shift perspectives more appropriately" (p. 27). To gain the perspectives needed to communicate effectively across cultures, students must be conscious of the cultural implications of their linguistic abilities; it is this cultural consciousness that needs to be emphasized. Recognizing the role of culture in communication is becoming increasingly important as cultural information is being exchanged at a rapidly increasing rate.

\subsection{Globalization and Japan's Important Position}

By looking at language teaching through the perspective of language determinism, it takes on a more humanistic role. Understanding of cultures and acquiring the opinions and logic of people outside your immediate community becomes an important task when teaching a language. What exactly is this consciousness that language learners must acquire? How does this specifically apply to EFL? How has globalization made this consciousness more acute and applicable to Japan? 
Globalization is "what happens when the movement of people, goods, or ideas among countries and regions accelerates" (Suárez-Orozco and Qin-Hilliard, 2004, p. 1). While people may disagree on the virtues of its achievements, globalization is undoubtedly an unstoppable force. However, despite its controversies, globalization, it is argued, has come about because of the humble desire for world peace (Ota, 2001). Kumaravadivelu (2008, p. 104) supports this conclusion: globalization "seeks to promote among the general public a genuine understanding of the value of cultural diversity in shaping national identity. It believes that discrete ethnic identities can be preserved within a larger national identity that unites disparate ethic groups." According to David Reiff's New York Times article (2006, March 26), "Globalization is both unavoidable and of great benefit to the world as a whole." A popular argument against globalization is that it leads to culture homogenization and threatens a citizen's national identity - old traditions are abandoned and forgotten in place of more cost effective and efficient ideas and processes. However, Harvard social anthropologist James Watson concluded in a study of globalization in Asian societies that globalization does not destroy cultural diversity by homogenizing cultural practices the world over (as cited in Suárez-Orozco and Qin-Hilliard, 2004, p. 20). He states that "local vectors always transform global products rendering them meaningful in terms of local sensibilities, social practices, and cultural models." As globalization brings the world closer, the need for more fluid intercultural communication increases; the consequences of this for Japan will be discussed.

In the context of Japan, history is riddled with the Japanese actively adopting global products and ideas and rendering them successes which are uniquely Japanese: the adoption of kanji into the Japanese writing system from China in the $4^{\text {th }}$ century (Seeley, 1991, pp. 12-19), Buddhism from the Koreans in the $4^{\text {th }}$ century (Quang, 1997), ceramics from the Koreans in the $17^{\text {th }}$ century (Lee, 2008), and science and technology from America in the Meiji Era (Fujimoto-Adamson, 2006). All of these examples have come to define Japanese culture. Being aware of how global forces impact a national identity is needed to manipulate globalization in a favorable way. Many of Japan's successes can be attributed to the acceptance of foreign ideas; similarly, many of its successes can be linked to taking advantage of global needs (e.g. the IT boom and Japan's subsequent semiconductor dominance). These successes were possible because of Japan's keen awareness of the ebbs and flows of global cultural needs. Therefore, one could argue that Japan's modern history has been built on its ability to harness a global cultural consciousness.

\subsection{The Internationalization of English}

In the current whirlwind of information sharing, English has become the language that has connected the world. Undoubtedly, English has emerged as the world language or a lingua franca in almost all settings (Phan, 2005). In a paper by Phan La Ha, 'International English' (IE) is a term which she adopts to describe English as it more accurately conveys the international use of English rather than implies that there is one clear variety of English that is superior to all others. She also clearly states that English, through the aid of globalization, has morphed into a language that is free from the rules of its source. Because no one society can claim the sole rights to English, and therefore its superior form, societies should be free to adapt this language to suit their local environment without a controlling body. Under this concept Singaporean-English, Indian-English, African-English, Australian-English, American-English, and British-English are all equal under the umbrella of IE. Therefore, IE is a global culturally conscious interpretation of the English language.

However, as Phan (2005) points out, there is still discrimination against different 'dialects' of English. For instance, American speakers or British speakers of English still exhibit a superior attitude and look down upon 'other' newly developed 'Englishes'. This concept of 'otherization' hinders the progress of IE usage and ultimately intercultural communication. Once IE matures to meet its potential, the otherization of English will disappear. Making English language learners more culturally conscious can accelerate the maturation of IE

English has the unique capabilities of taking on the emotions and cultural peculiarities of other cultures. In the book English and Ethnicity, Catherine Evan Davies (2000) writes:

English itself must be conceptualized not as a monolithic linguistic entity with one 'standard' form....English can be used to 'signal' a wide range of ethnicities in a wide range of contexts, and no one feature or variable has an inherent semiotic value. Such a perspective recognizes not only the importance of culture as context, but also the reflexive relationship between context and language. (p. 5)

This concept is echoed in the idea of IE.

IE, therefore, has the special nature of being used in different language-realities, and thus, to a certain extent, has evolved to violate the principle of language-determinism; it is a tool used to communicate over multiple language-realities - the ultimate language of $\mathrm{C} 3$. The concept of IE, the language facilitator of globalization, must be embraced by Japan in the same way it has been embraced by Singapore (to take an Asian example).

\subsection{The Japanese Cultural Shift}

According to Ota (2002), a number of shifts from traditional Japanese language values to more international language ideals have already occurred. Some sociolinguistic and pragmatic changes include an increase in the following: 
confrontational and aggressive sentence structures, agreement-demanding phrases, self-righteous and non-apologetic language; egalitarian communication, new idiomatic usages, and loan words form English.

This change signals the start of a positive change in the language-identity of Japan; an identity change that is needed to function in the global community; and with language changes there are cultural changes. Norio Ota (2002) also lists the following major areas of Japanese society that have been hit hardest by globalization in the very recent past: judicial system reform, empowerment, psychological analysis, aging and tax reform, attitudes towards multiculturalism, education, marriage, political correctness, restructuring, free trade, and power sharing. Japan must continue to embrace more global language values.

\subsection{A Teachable Moment in Japan}

Not only has Japan been a receiver of globalization, but it has also been a major giver. Japan's cultural exports include: manga, animation, technology, automobiles, and fashion. Tremendously influential global forces from Japan have come in the form of director Hayao Miyazaki, Sony, Toyota, Harajuku fashion, and animations such as Ghost in the Shell or Naruto. Because Japan has a multidirectional exposure to globalization, Japan has the potential to both reflect on itself as an instrument of globalization and as a victim of globalization. Herein lays Japan's advantage in the journey to create a more global culturally conscious identity: with so much back and forth interaction between Japan and the rest of the world ( $\mathrm{C} 1$ and $\mathrm{C} 2$ ), how could Japan not succeed in being more globally aware (C3) if it simply recognized its relationship with the rest of the world?

Japan must capitalize on its current position at this vital stage in globalization and embrace IE as its own. Henry Jenkins points out that this widespread cross-cultural exchange between countries has produced a "teachable moment" in which societies have an opportunity to make incredible progresses in education (as cited in Suárez-Orozco and Qin-Hilliard, 2004, p. 20). Japan, in particular, has the tools to transform this "teachable moment" into large gains in the field of intercultural communication.

\subsection{Japanese English Education and its Economy}

Japan, a country which has depended on adapting to changing global conditions for its survival, is now at a pivotal stage in its history. L'estrange points out there is an imminent fear within Japan that they will be "under represented in the international community" if its leaders are not able to speak English "directly with their counterparts" (as cited in Phan, 2005, p. 11). Japan, certainly, has awoken to the important role that English will play in its future. In the words of Toyama Atsuko, the former Japanese Minister of Education, Culture, Sports, Science, and Technology (MEXT, 2003):

English has played a central role as the common international language in linking people who have different mother tongues. For children living in the 21st century, it is essential for them to acquire communication abilities in English as a common international language. In addition, English abilities are important in terms of linking our country with the rest of the world, obtaining the world's understanding and trust, enhancing our international presence and further developing our nation.

The concept of IE and its ability to penetrate cultural barriers has certainly, if not rather indirectly, been acknowledged by educational officials in Japan.

This same idea is reflected in how Japan is approaching its economic barriers. In the 2007 annual white paper on international economy and trade, Amari Akira, the Minister of Economy, Trade, and Industry (MITI, 2007), highlights this same unique moment in Japanese history:

The year 2007 marks the 60th anniversary of Japan's re-opening of private trade. In the upheaval of the post-war period, there continued to be a period when only the minimal necessary imports and exports were permitted; however, by June 1947 trade transactions by private companies were re-opened, although only within stipulated limits. Since then, Japan has continued to expand its trade transactions as a standard bearer "Trade powerhouse," with trade reaching its highest-ever level in 2006. Presently, in our country, [our society is plagued] with a decrease [in] birthrate and an aging population. In such circumstances, productivity must be raised even higher than previously, and economic growth sustained, if Japan in the future is to be a society with a vigorous economy. In order to achieve this, it is necessary for Japan to take advantage of its strengths, to overcome its weaknesses, and to seek out opportunities for growth around the world through further expansion of trade and of external/internal direct investment.

It seems clear that MITI and MEXT have overlapping goals: to make the Japanese population effective cross-cultural communicators so Japan can take advantage of financial opportunities overseas. Communication, in fact, is Japan's weakness, but one it has admitted to and is willing to fix. According to an article in Newsweek by Akiko Kashiwagi and Christian Caryl (2008, May 12), Japan's share of the global economy has slid from 18 percent in 2004 to 10 percent in 2006; a decrease that is indirectly "linked to the striking lack of conversational English among educated Japanese." In reality, even though Japan has the opportunity, tools, and position in the world to conquer its weakness, it appears to be struggling. 
Historically, Japan has been able to reach across borders and change internally to retain a command in the global marketplace. Japan has the experience and wealth to remedy its problems through implementation of culture-based education that overflows into business. From what I have discussed in this first part of my paper, instilling in Japan's population a global cultural consciousness can solve problems in its service, trade, and investment sectors; it can bring Japan new ideas for innovation; it can change its attitude regarding foreign business; and it can revamp Japan's cultural identity so that it works well in the $21^{\text {st }}$-version of globalization. As all the indicators point so clearly in one direction, the opportunity of a "teachable moment" has arisen in Japan.

\section{Pedagogical Steps for Creating a Global Cultural Consciousness in the Classroom}

The key to bridging the gap between the communication abilities of Japanese now and the ideals of MEXT and MITI is to create a global cultural consciousness in the classroom. Such a global consciousness requires the cultivation of a critically reflective mind that can tell the difference between information and disinformation, between real and unreal ideologies. "Only such a critical mind can help the individual develop the knowledge, skill, and disposition necessary to deal with the challenges of contemporary realities" (Kumaravadivelu, 2008, p. 164). In the Japanese public school system, teachers adopt teaching methods used by teachers who taught them; specifically, Confucius-style teacher-centered techniques, memorization, and grammar based translation methods that are controlled by strict rules (Taguchi and Naganuma, 2006). There is little chance for the student to critically reflect on the meaning and purpose of English.

For the remainder of this paper, I will focus on pedagogical steps to creating a globally culture-conscious EFL classroom. Because, for the time being, there is little opportunity to more easily apply new methodologies in the Japanese public school classroom, I will discuss the implementation of techniques in the context of private English language institutes, specifically for adults with the purpose of using English in business. I have developed and tested several instructional techniques that ELT professionals in Asia and elsewhere might find useful. I would now, therefore, like to discuss one specific approach for promoting intercultural global cultural consciousness that I have successfully used in the past with Japanese EFL students who study English for business purposes. The lesson plan that will be discussed incorporates five key cultural factors into the classroom and employs the anthropological technique of ethnography.

\subsection{The Five Cultural Factors}

According to Kumaravadivelu (2008, pp. 170-171), the following five factors need to be recognized in curriculum for the successful integration of culture into the EFL classroom in the current globalizing environment.

\subsubsection{Cultural Connectivity}

Cultures do not exist in isolation. In reality, they are rarely found in their purest form - cultural boundaries are just an illusion. Although culture is normally associated with a national identity, it functions at various sub-levels such as race, religion, ethnicity, class, and gender. Culture is multifaceted and layered.

\subsubsection{Cultural Complexity}

Because culture itself remains an elusive concept, cultures outside ones own are not clearly understood. This leads to stereotyping and otherization. We stereotype people we don't understand, and others stereotype us. "Other" cultures who present themselves as religiously, racially, ethnically, or linguistically different are improperly considered inferior.

\subsubsection{Cultural Globality}

The current wave of globalization is shaping the global flows of culture with unprecedented speed. There are simultaneous and opposing forces of cultural homogenization and heterogenization, twisting the world into uncomfortable positions that sometimes are seen to weaken local cultures and sometimes strengthen them. Some people are empowered by this awareness while others feel threatened.

\subsubsection{Cultural Reality}

Modern cultural life is being influenced by four realities: the global reality that shrinks space, time, and borders; the national reality that fosters nationalism as a reaction to cultural homogenization; the social reality that is created through families and communities; and the individual reality that depicts the individual as complex and dynamic.

\subsubsection{Cultural Identity}

The realities above impact the formation of cultural identity. The commodification and marketing of cultural products within the global free market can also influence identity. The individual's identity is in constant motion, yet there is also a degree of control an individual can have over identity.

The application of each of the five factors above into the EFL classroom will be discussed and pedagogical steps to do this will be suggested. 


\subsection{Teaching Based on Ethnography}

As with many adult private language schools in Tokyo, my school's students are mostly corporate clients with business related study goals; this means that companies are requiring their employees to learn business English in order to operate in the global corporate world. Because of the "trade powerhouse" nature of Japanese business, many of my students travel overseas to meet clients multiple times a year or interact directly with overseas partners on a regular basis. The Japan External Trade Organization website lists the USA, China, Korea, Hong Kong, Taiwan, and Germany as Japan's top trading countries; in fact, these same places are the most popular destinations for my students' business trips. The assumption that many Japanese business people have regular exposure to foreign culture is made for the purpose of this lesson plan.

To fully integrate culture into the classroom, I suggest the method of ethnography be used. According to Robinson:

Ethnography is a method taken from social anthropology to obtain cultural information about the target culture. Ethnographers not only observe, but also participate... ethnographers lose objectivity and interpret things from a native's point of view... getting an inside, emic account of culture. (as cited in Kumaravadivelu, 2008, p. 182)

In the case of Japanese businessman, there are many real experiences that can be used to investigate culture as an ethnographer. Emailing, talking on the phone, meeting clients, or going overseas on business trips could be opportunities for students to gather cultural information. For the following lesson plans, I will choose an extended business trip to a foreign country as the ethnographic setting. I will also assume that when going to this country, be it China, the USA, Germany, or anywhere else, they will speak English. Given the status of English as an international language, this is a fair assumption.

The task that I propose is for the student to write a diary outlining their experiences in detail while on their overseas business trip. The diary should include both cultural observations and activities that the student participates in. Teachers should encourage students to document behavioral culture (for example, taking off one's shoes before entering a house) and material culture (for example, electric toilet seats). The diary is then used in class and exercises are done which critically analyze their experience in terms of the five cultural factors above.

This type of ethnographic method is called critical ethnography. Critical ethnography is "a written investigation that takes into account historical, political, sociological and other macrocontextual factors of another culture" (Kumaravadivelu, 2008, p. 183). Another ethnographic technique I will utilize is autoethnography, which is "an autobiographical genre of writing that displays multiple layers of consciousness, connecting the personal to the cultural" (Kumaravadivelu, 2008, p. 184). In this case, information is collected by the student in the form of a diary, and the multiple layers (the five culture factors) will be added with the aid of the teacher upon reflection on the experience. Autoethnography is chosen as an appropriate example of a culture teaching method because it gives cultural information to the student via real experience, it allows for critical reflection of foreign culture and Japan's culture, and it provides an opportunity for the student to reevaluate their own cultural self.

After completing the diary and returning from the business trip, one class is spent on each of the culture factors, as outlined in the lesson plan below.

Note that the following lessons assume a one-on-one class structure; however, it could be easily adapted to suit group classes. Cultural topics for each lesson below are examples only; in reality, cultural problems will depend on the experiences documented in the student's diary. Additionally, I should be clear that although the following lesson plans have been tested with success, the diary entries used in this paper are fictional and not written by an actual student. In writing the fictional entries, I did my best to incorporate popular viewpoints from previous students.

\section{The Lesson Plan}

\subsection{Day 1: Cultural Connectivity}

The goal of this first lesson is for students to gain a sense of interconnectedness between the foreign culture (C2), as documented in the student's diary, and Japan's culture (C1) on the national level and on a subculture level.

\subsubsection{Choosing a Situation}

Go through the student's diary and have them select an experience in which they felt culturally awkward. A fictional extract from a student's diary depicting an unfamiliar situation is given below.

On my last day in Washington D.C., an important client took me out for lunch. I insisted that I pay as it was the least I could do in return for his gracious hospitality. Having paid in full and ready to leave the restaurant, my client explained that it was a custom to leave a tip for the waiter. I left what I thought was a reasonable sum and left with my companion. Before exiting, my client excused himself, went back to the waiter who had been serving us, and gave him more money. Upon seeing this, I felt embarrassed. 


\subsubsection{Presentation of the Cultural Problem}

After a brief discussion, it will become obvious that the lack of understanding of "tipping" is the root cause of the student's discomfort. Delving deeper, although the student had a superficial knowledge of this cultural practice, the actual amount to leave as a tip was what led to the predicament. Arriving at the acceptable rule of leaving a tip of $15 \%$ to $20 \%$ of the bill could ease the practical difficulties for the student of this arising again. During the discussion, useful language can be discussed for the purpose of reenacting this situation as a role-play language activity. For example: "it's on the house," "it's on me, "it's my turn," "I'll pick up the bill this time," "keep the change" or other standard restaurant phrases could be presented.

\subsubsection{Language Task}

Role-play the act of offering to pay and giving a tip several times, paying careful attention to using new idioms and vocabulary. After each role-play, introduce difficulties such as: "you offer to pay, but you find out you don't have enough money," "your colleague has paid, but he has not left a tip," or "both you and your client feel very strongly about paying." Assist as necessary as the student struggles through each situation. Practice interaction between both the waiter and the other dining companion. Contrast appropriate language used when talking to a waiter as opposed to a client or colleague. Phrases such as "I wonder if....," "Would you mind...," or "It might be a good idea..." are some examples of indirect requests or suggestions. Discuss how indirect phrases could be used in a sensitive situation like this one, which involves money, or other situations that require a degree of tact. Discuss polite language that might be appropriate for the waiter or host of a restaurant to use.

\subsubsection{Cultural Exploration of Behaviors}

Form a list of jobs with the student in which it is socially normal to tip. Discuss reasonable amounts to tip a waiter, a bellboy, a housekeeper, a taxi driver etc. Discuss ways in which Americans can justify leaving a sizable tip. The student or teacher may point out that for certain service jobs that have an extremely high number of transactions or a deal with large sums of money, the total tip income may be incredibly high. The example of the service industry in Las Vegas may be useful in illustrating how the income of a bartender is often higher than the income of a doctor. Discuss the fairness of tipping and some possible problems in a tipping society. Eliciting more pros and cons can set up a debate between the teacher and student

\subsubsection{Establishing a Cultural Connection between C2 and Japan}

Discuss reasons why tipping is not practiced in Japan. Comparing the minimum wage in Japan to that of the US may result in the student understanding that it would be difficult for a person to survive on a US minimum wage without tips, yet it is easier for an employee earning a higher Japanese wage. Considering the prestige of Japan's customer service industry, discuss whether Japan would benefit from the introduction of tipping in its society. Many Japanese are surprised at the lack of efficiency and politeness of customer service overseas. This perceived high quality of Japan's customer service can be partly attributed to Japanese honne and tatemae feature. Discuss how honne and tatemae is applied to the customer service industry in Japan. Does the student agree that the distance between honne (how you really feel) and tatemae (what you appear like) in the customer service industry is large? If yes, possible reasons the student may come up with is that it 'avoids conflict' or 'saves face.'

\subsubsection{Autoethnographic Analysis}

As a final post-class exercise, the student can write a critical analysis of their $\mathrm{C} 2$ experience taking into account any new perspectives gained from this class. Students can also write about how they would act differently if they were in this situation again, or how they would react if they were a foreigner in Japan.

Upon concluding lesson 1, the student will have an understanding for the reasons of tipping in some societies and reasons for not tipping in others (minimum wage, tatemae and honne mindset etc.) This understanding builds a bridge that connects Japanese culture with other cultures, and creates a greater sensitivity towards other people. Other 'foreign' cultural practices can be appreciated so long as the resulting awareness of cultural connectivity is established.

\subsection{Day 2: Cultural Complexity}

The goal of this second lesson is to use situations documented in their diary to challenge stereotypes of foreign cultures as perpetrated by the media or inaccurate preconceived beliefs. Students can begin to acquire a consciousness of the complexity of individuals and groups within a culture.

According to my experiences teaching Japanese businessmen, American stereotypes, as seen from a Japanese business viewpoint are: acting superior, not wanting to share credit, unwilling to adjust to local cultures, preferring solutions based on their own customs, encouraging individual performance over collective efforts, being disloyal to clients and their own company, and being pushy, imposing, or too direct. 


\subsubsection{Choosing a Situation}

Brainstorm common stereotypes Japanese have of foreigners. After that, go through experiences with the student in which they discovered a stereotype of C2's culture was not true. A fictional extract from a Japanese businessman's diary which contradicts one of these stereotypes is given below.

On my second day, I visited the president of our client's company. As part of our introductions and cordial small talk he proceeded to give a brief outline of his career. Though it was a company with over 10,000 employees, he worked his way up through various positions in the company for 35 years until he was finally named president. He said that he turned down a lot of job offers throughout his successful career because he felt a connection with the company and wanted it to grow with it. I was impressed by his dedication to his company.

\subsubsection{Presentation of the Cultural Problem}

The stereotype that is broken here is the one that American workers are disloyal to their companies. The student needs to recall reasons why he was surprised. Possible reasons could include past experiences with other clients, portrayal of business in the media, or differences in how Japanese view their companies. List reasons an employee should stay with one company for an entire career. While eliciting reasons, present new vocabulary to the student - lifetime employment, benefits, educational reimbursement, internal promotion, career advancement, severance package etc.

\subsubsection{Language Task}

Ask the student why he would or wouldn't stay with the same company for the rest of his career. Encourage students to use vocabulary that has been introduced. Present idioms or new vocabulary as needed. Perform a debate with the student on the topic of staying with a company for an entire career. Introduce language of opinion. Allow students to debate both sides so the student intellectually explores all viewpoints.

\subsubsection{Cultural Exploration of Behaviors}

Take all reasons from the previous language task and divide each of the reasons into two categories: common reasons for Japanese staying with/leaving their jobs, and common reasons for Americans staying with/leaving their jobs. Most Japanese will immediately pounce on the fact that Japanese workers are incredibly loyal and often work for one company their entire life. Discussing reasons for higher overall employee loyalty in Japan may yield the following explanations: Japanese emphasize development as part of a group from a very young age (soto versus uchi), companies are skeptical of job candidates who have worked for many companies, or Japanese are less 'risky' people. On the other hand, if students are pressed to give advantages of leaving a company, they might give 'higher salary', 'more opportunities', or 'better work environment' as reasons. Issues such as the Japanese concept of 'lifetime employment' could be discussed as something that either benefits employees or makes companies less efficient. At the end of the discussion, discuss the extent to which they understand why people leave their jobs.

\subsubsection{Validity of the Stereotype}

Now that the student understands that this stereotype is not always true, decide to what degree that the stereotype could be true. Does the student think Americans hold the opposite stereotype of Japan - that Japanese are blindly loyal to their companies? To what extent is this true?

\subsubsection{Autoethnographic Analysis}

As a final post-class exercise, students may use their new perspectives on American loyalty to write a critical analysis of another experience they have had in which they have misjudged a person because they have wrongly assumed a stereotype to be true.

The goal should be to arrive at a conclusion that this stereotype is either misleading or true to a certain extent. For example, a student might conclude "Americans do have less problems changing companies mid-career for certain reasons, but they are also loyal if they are treated well. On the other hand, although it is understandable that Japanese may be thought of as viciously loyal, there are certain instances where they choose themselves over our companies." This questioning of stereotypes is necessary for students to begin understanding other cultures.

\subsection{Day 3: Cultural Globality}

The goal of this third lesson is to compare Japanese culture with $\mathrm{C} 2$ and find any culture overlaps that may indicate global culture homogenization. Critically looking at both whether globalization has compromised Japanese local customs and the affect of Japanese culture on the world will give students a sense of how globalization is impacting people's lives - a consciousness of culture globality.

\subsubsection{Choosing a Situation}

Select with the student an experience recorded in their diary when they witnessed Japanese culture influencing C2's culture. A fictional diary entry below illustrates a moment of realization when the author is confronted with a form of Japanese culture in the US. 
After spending a week in hotel rooms and not turning on the TV, I decided to flip through the channels to get a sense of what was shown on American TV. I was shocked to see Naruto on the Cartoon Network, and My Neighbor Totoro shown on the movie channel. I switched back and forth between the two remembering watching the episode of Naruto about 8 years earlier in Japan. My Neighbor Totoro also brought back memories. It was also strange to hear that these two programs had been dubbed in English. It felt like something was lost in translation. I told my American customer about what I had seen on TV and he said that not only had Japanese animation become extremely popular in the US, but his own daughter's favorite movie was Hayao Miyazaki's Spirited Away.

\subsubsection{Presentation of the Cultural Problem}

This passage is a clear example of how Japan has been a globalizing agent. Some authors have called this "Japanophilia" or an "infatuation with Japan's cultural character" (Kelts, 2006, p. 5). It is important to discuss with students whether or not they were aware of Japan's worldwide cultural influence. It is surprising how many students are unaware of this. Animation is the cultural export in this example, but there are many other cultural exports that student should be able to recognize; these may include comics (manga), video games, samurai (bushido) and ninja tradition, flower arrangements (ikebana), tea ceremonies, business practices such as quality control, technology, and influential companies such as Toyota, Sony, Kawasaki, and Honda.

\subsubsection{Language task}

Have the student choose an activity, cultural item, or behavior which is uniquely Japanese. For example: sumo wrestling, a certain genre of comic, a ryokan (Japanese style hotel), the concept of a samurai warrior, a kimono, Zen Buddhism, or shodou. Then have the student try and explain in detail what the item/activity is and why it is uniquely Japanese. Introduce descriptive language; not only vocabulary but also similes and metaphors. Practice for other items/activities or behaviors.

\subsubsection{Cultural Exploration of Behaviors}

Ask students how they would feel if the items mentioned in the above language task were changed in order to be marketed to people in other countries. Do students believe that foreigners have a full understanding of certain exported Japanese traditions, or do they have certain cultural features that cannot be translated? Have any sacred cultural beliefs been trivialized and/or diluted? What is the significance of this? Does it help preserve or deteriorate Japanese culture? Discuss and debate the possible benefits and detriments of exporting Japanese culture.

\subsubsection{Being Aware of Culture Globality in Japan}

Brainstorm examples of how Japan has changed in the face of globalization - increased use of English, European and American fashion trends, and adoption of western eating habits are some. An example which may relate business to globalization is the appointment of Brazilian-Lebanese Carlos Ghosn to the CEO position of Nissan. The decision to bring in foreign leadership to Japanese companies has caused controversies. List the pros and cons of foreign influence in Japanese business and debate opposing viewpoints.

\subsubsection{Autoethnographic Analysis}

After discussing specific examples, the student can further write on the significance of Japan's role in globalization: Does the student think Japan is the victim of the homogenization of world cultures, or does the student believe Japan has been the benefactor of the positive effects of globalization? What are some experiences the student has had to illustrate his viewpoint on globalization?

Upon conclusion of this lesson, the student should have an increased awareness of the rapid and multi-directional flow of culture capital around the world.

\subsection{Day 4: Cultural Reality}

The goal of this fourth lesson is to recognize how observable reality has become increasingly more complex. Political, racial, religious, and various controversial relationships seem to have come to a head. Critically viewing this reality will allow students to appreciate how important it is to have a consciousness regarding these issues.

\subsubsection{Choosing a Situation}

Select an experience outlined in their diary where they experienced or witnessed a national controversy. A fictional diary entry below depicts an experience involving controversy on a business trip to Seoul, Korea.

After finishing a meeting in the business district of Gangnam, I caught a taxi back to Lotte Hotel which was next to Seoul city hall. The taxi trip was delayed because of what appeared to be a large demonstration outside the government buildings in the area. I opted to get out of the cab a few block from the hotel and make my way through the crowd of people. Some of the signs that were held up in protest were written in English. They read "No Free Trade" and "Say No to USA Beef." I learned on the news that over a thousand Koreans participated in the protest over free trade. I was surprised by the shear size of the demonstration and the anger of the people who took part. 


\subsubsection{Presentation of the Cultural Problem}

The event documented is a protest in Seoul, Korea, by opponents of a beef import agreement with the US. Reasons for the protests could be explored with the students. Fear of importing US beef contaminated with mad cow disease and opposing free trade are some reasons for this kind of protest. Discussions with the student about similar controversies in Japan could spawn the topic of tainted food imported from China or free trade disagreements raised by Japanese rice farmers.

\subsubsection{Language Task}

Note that Japanese students will often be surprised at the level of emotion and intensity Koreans express when disagreeing with their government. Introduce students to language techniques for expressing anger and emotion - direct language, active voice, threats, and ultimatums might be some appropriate language. For this language task choose a controversy in Japan discussed above and list a few opinions on how the student would like the government to react to the situation; have the student present his views in the form a presentation directed toward the government. Encourage students to be direct and emotional. This is likely to go against the natural rhetoric of pathos of traditional Japanese communication which tends to avoid confrontation (Maynard, 2005, p.34-36). This is an opportunity to highlight the honne and tatemae and uchi and sato characteristics of Japanese society in contrast to the Korean's emotionally charged personality.

\subsubsection{Cultural Exploration of Behaviors}

Discuss with students the advantages and disadvantages of importing cheaper but lower quality food from other countries. Debate the pros and cons of this issue. A similar activity could be done for free trade. Discuss and debate how a rice farmer in Japan benefits and loses from free trade. How is Japan currently handling its controversies? Discuss how other societies deal with similar problems - protectionist policies, diplomacy, threats, dumping, price fixing, tariffs etc.

\subsubsection{Handling of Japanese Controversies}

Does the Japanese government do an effective job of handling its current globalization-related problems? Some additional examples to the ones above could be: the Yasukuni shrine, right-wing political activities, the decreasing population, changing the Japanese constitution to include military rights, the Iraq War, and the Beijing Olympics. Explore the merits of Japanese government strategy on topics which interest the student.

\subsubsection{Autoethnographic Analysis}

Using ideas from this lesson, the student can write a formal letter of complaint to the government on the topic of a conflict in Japan. The letter should criticize the government's handling of the crisis and offer alternative strategies. Encourage students to use personal experiences to illustrate their discomfort with the government's stance. Giving the student a taste for activism will make the student more aware and conscious of their cultural reality.

This lesson should highlight some of the complexities that can arise because of globalization and the consequential mixing of cultures. The student should realize that in such cultural complexity there are few black and white truths, and because of the grayness of cultural connectivity, culture clashes are becoming increasingly problematic.

\subsection{Day 5: Cultural Identity}

The goal of this fifth lesson is to reflect on cultural connectivity, cultural complexity, cultural globality, and cultural reality as it relates to the student's experiences, and analyze how their basic attitudes towards their own culture and towards other cultures have changed as a result of this critical reflection. This is the final step in taking cultural information and turning it into cultural transformation. The student will learn to redesign their own identity that incorporates a new global cultural consciousness. In this lesson the transformation to a $\mathrm{C} 3$ identity will be explored.

Regarding the previous four fictional diary entries, the student and teacher could make the following conclusions.

\subsubsection{Cultural Connectivity}

Each culture partially overflows into our own. Even though foreign practices, such as 'tipping,' may seem inappropriate and illogical on the surface, they serve an important purpose in that society. As a result, time should be taken to thoroughly understand the significance of these practices when participating in them. It is not only possible but also our duty to respectfully practice and appreciate other culture traditions.

\subsubsection{Cultural Complexity}

Stereotypes prevent a person from fully understanding a culture group outside their own. Any belief should be doubted and investigated unless evidence is available to prove its validity. It is ignorant to generalize over groups and individuals within a culture. An assumption of diversity is needed before interaction. 


\subsubsection{Cultural Globality}

Not only have other cultures invaded Japan, but Japanese culture is a major influence in other countries. With every negative aspect of globalization comes at least as many positives. If globalization is blamed for the destruction and dilution of traditional Japan, then it also must be credited with the promotion and success of Japanese ideas around the world.

\subsubsection{Cultural Reality}

Conflict and controversies are a consequence of dealing with other cultures. These negative side effects can be minimized if we are conscious that right and wrong is relative and depending on a society's viewpoint. Recognizing that people are different can help us be sensitive to other's beliefs, and nullify some of the resulting conflict.

\subsubsection{Final Task}

As a last authoethnographic exercise, have students imagine they were the foreign teacher of the class. Then have the students write a fictional account of their experience in Japan from the perspective of their foreign teacher. Encourage them to use the ideas of cultural connectivity, cultural complexity, cultural globality, and cultural reality to help them see Japan from a new point of view. The goal of this final task is to see themselves and their culture through a culturally conscious perspective.

Transforming someone's culture identity is, as Montovani (2000, p. 14) put it, "when a journey leads us to expand the boundaries of our own identity to the point at which we include in the 'we' what was previously simply 'other,' our journey is a return home, we come full circle" (as cited in Kumaravadivelu, 2008, p. 180) At the end of this final lesson, the student should have come "full circle" bringing with them a new identity that will affect how they view the world and approach other cultures.

\subsection{Difficulties in Implementation}

Because the above lessons depend on an overseas business trip, this may be difficult (and costly) to implement for students who do not travel frequently; therefore, teachers must be fairly flexible. I have found that students are fairly quick to recollect specific episodes from vacations or overseas experiences in their past; in fact, culture and cultural experiences, it seems, can be very easily discussed with most Japanese students. Sufficient preparation and specific instructions on what to document before the student travels are recommended in order to smooth out any difficulties in selecting appropriate diary entries. Again, teachers must be flexible as experiences may not exactly fit in perfectly with one of the five cultural factors. In general, if a student has had or is planning to have an experience which exposes him/her to another culture, my lesson plan will be successful with few difficulties.

\section{Concluding Discussion}

Beyond the actual lesson, there are many other routes to increasing the global cultural consciousness within the classroom. From policies and planning to materials used in the classroom, factors outside of teaching methods contribute greatly to a student's cultural and language learning.

The concept of IE can only be taught in the classroom by changing the focus from a "traditional" language community to a global cultural community. Both public schools and private schools in Japan have a disproportionately high number of American, British, and Canadian teachers; the reason being that the teaching of language and culture needs to be confined to the practices and beliefs of the "traditional" language community. This idea neglects the student's need for developing a global cultural consciousness. Teaching IE must first start with cultural diversity among teachers. Teachers who speak with different accents, pronunciations, and vocabularies expose students to different worlds of English; teachers who come to the classroom armed with "strange" arsenals of idioms and peculiar slang only make the student more aware of the different acceptable forms of English around the world. The teacher's culture (C2), therefore, should not be a model by which the student's culture (C1) is transformed into; rather, the student should aspire to an in-between culture (C3). Thus, the perspective of $\mathrm{C} 3$ should be such that the student has a language awareness that spans a global community of cultures. Carefully choosing a community of language teachers based on factors such as global prominence, emerging prominence, and political relevance is essential. American, Canadian, British, Indian, Chinese, German, and Islamic regional English speakers would be an example of such a community.

Students should be encouraged to use English expressions associated with their ethnic, racial, and cultural identities in innovative ways. British linguist Ben Rampton (1995) called this crossing. He noticed that in language performances, students preserved their cultural identities by using new expressions grounded in their knowledge of "neighborhood, class, gender, age, sexual orientation, role, and recreational interest" (pp. 312-313). In Japan, a common crossing example is the popularly spoken phrase "Let's challenge English." The verb challenge is used in a non traditional way, yet is derived from a cultural interpretation. Such examples are not inappropriate in the definition of IE; they preserve $\mathrm{C} 1$ while also moving the student towards $\mathrm{C} 3$ (never arriving at or even completely directed at $\mathrm{C} 2$ ). 
Textbooks sometimes have an uncontrollable authority that influences not only students but also teachers. Using authentic and appropriate materials is needed. One major problem with textbooks is that they are widely acknowledged as not being a neutral medium (Kumaravadivelu, 2008, p. 188). They hold a worldview that is directly or indirectly forced onto the teacher and student. One way to bypass this obstacle is to use authentic materials. Former Kwansei Gakuin University assistant professor Derrick Nault, in his paper Using World Literatures to Promote Intercultural Competence in Asian EFL Learners, suggested a method called the Intercultural Approach to Literature Teaching (IALiT) which uses examples of world literatures to teach intercultural communication. Nault (2006) recommends using "works in English by authors from regions of the world where English is regarded as a second or foreign language" (p. 140). He argues that by analyzing excerpts from these texts, students both improve their English skills and gain what he calls "international intercultural competence." One technique he utilizes is called Culture Clashes. This method brings authentic texts to the classroom, increases a student's cultural awareness, and gives evidence and examples to the concept of IE.

Currently Japan is facing an education crisis. Both the MEXT and MITI agree that English skills need to rapidly develop within the Japanese population in order for Japan to remain competitive in the global marketplace. In this time when culture flow is accelerating both into and out of Japan, a teachable moment has been created and must be capitalized upon. More than being just adept at the mechanical features of English, Japan needs to incorporate culture teaching into its EFL curriculum. A global cultural awareness is the missing link connecting Basic English competence and fluent intercultural communication. Unfortunately, teaching skills that promote cultural awareness do not fit in well with traditional methods of teaching in the Japanese public school system. Ethnography, inclusion of the five cultural values into curriculum, creating a target cultural community among teachers, using authentic texts, and the recognition of the concept of IE are some ways I have suggested to do this. The more Japan sees English as a window into other cultures and as an opportunity to transform its cultural identity, the better prepared it will be to handle life in the $21^{\text {st }}$ century.

\section{References}

Critchley, M. (1998). Design and Implementation of a Communicative Approach for Entry-Level University Students.

Retrieved on April 20, 2008, from http://www.encounters.jp/mike/professional/publications/publistjp.html.

Davies, C. (2006). English and Ethnicity. New York: Palgrave MacMillan.

Fishman, J. (1985). Variance and Invariance in Language Form and Context. Michigan: Mouton.

Fishman, J. (1991). Reversing language shift. Clevedon, Avon: Multilingual Matters Ltd.

Fujimoto-Adamson, N. (2006). Globalization and History of English Education in Japan. Asian EFL Journal, 8(3). Retrieved on September 12, 2008, from http://www.asian-efl-journal.com/Sept_06_nfa.php.

Gee, J. (1993). Introduction to Human Language: Fundamental Concepts in Linguistics. LA: Prentice Hall.

Japan External Trade Organization. Japan's International Trade in Goods 2008 [Data File]. Retrieved on October 20, 2008, from http://www.jetro.go.jp/en/reports/statistics/.

Kashigawa, A. \& C. Caryl. (2008, May 12). This Nation is an Island. Newsweek. Retrieved on September 19, 2008, from http://www.newsweek.com/id/135288.

Kelly, L.G. (1969). Twenty-Five Centuries of Language Teaching. Rowley Mass: Newbury House.

Kelts, R. (2006). Japanamerica. New York: Palgrave Macmillan.

Kumaravadivelu, B. (2008). Culture Globalization and Language Education. New Haven: Yale University Press.

Lee, J, (2008). The serene beauty of Korean ceramics. Korea Policy Review. Retrieved on June 19, 2008, from http://www.korea.net/news/news/NewsView.asp?serial_no=20080608001\&part=106\&SearchDay=.

Mantero, M. \& Y. Iwai. (2005). Reframing English Language Education in Japan. Asian EFL Journal, 7(2). Retrieved on September 30, 2008, from http://www.asian-efl-journal.com/June_05_mm\&y.php.

Maynard, S. K. (2005). Japanese Communication: Language and Thought in Context. Honolulu: University of Hawaii Press.

Ministry of Economy, Trade, and Industry (MITI). (2007). White Paper on International Economy and Trade 2007. Retrieved on September 30, 2008, from http://www.meti.go.jp/english/report/data/gWT2007fe.html.

Ministry of Education, Culture, Sports, Science, and Technology (MEXT). (2003). Regarding the Establishment of an Action Plan to Cultivate

"Japanese with English Abilities." Retrieved on September 20, 2008, from http://www.mext.go.jp/english/topics/03072801.htm. 
Nault, D, (2006). Using World Literatures to Promote Intercultural Competence in Asian EFL Learners. Asian EFL Journal, $8(2), \quad 132-150 . \quad$ Retrieved on $\quad$ September $15, \quad 2008$, from http://www.asian-efl-journal.com/June_2006_EBook_editions.pdf.

Ota, N. (2001). Impact of globalization on Japanese language and culture. Retrieved on October 12, 2008, from http://buna.arts.yorku.ca/japanese/ejlt/globalization.pdf .

Phan, L. (2005). Toward a Critical Notion of Appropriation of English as an International Language. Asian EFL Journal, 7(3). Retrieved on September 12, 2008, from http://www.asian-efl-journal.com/September_05_plh.php.

Quang, D. (1997). Buddhism in Korea. Retrieved on June 2, 2008, from http://www.buddhismtoday.com/english/world/country/027-korea.htm .

Rampton, B. (1995). Crossing Language Ethnicity Among Adolescents. London: Longman.

Reiff, D. (2006, March 26). Globalization 2.0. The New York Times. Retrieved on December 29, 2008, from http://www.nytimes.com/2006/03/26/magazine/326wwln_lede.2.html?_r=1.

Riley, P. (2008). Reform in English Language Teaching in Japan. Kanto Gakuin University Department of Human and Environmental Studies Bulletin. 6(9). 105-111. Retrieved on October 12, 2008, from http://opac.kanto-gakuin.ac.jp/cgi-bin/retrieve/sr_bookview.cgi/U_CHARSET.utf-8/NI20000267/Body/link/105-111.pd f.

Salzmann, Z. (1993). Language, Culture, and Society: An Introduction to Linguistic Anthropology. Colorado: Westview Press Inc.

Seeley, C. (1991). .A History of Writing in Japan. Honolulu: University of Hawaii Press.

Suárez-Orozco M. M. \& D. B. Qin-Hilliard. (2004). Culture and Education in the New Millennium. Berkley, L.A.: University of California Press.

Taguchi, N \& N. Naganuma. (2006). Transition from learning English to Learning in English: Students' Perceived Adjustment Difficulties in an English-Medium University in Japan. Asian EFL Journal, 8(4). Retrieved on September 14, 2008, from http://www.asian-efl-journal.com/Dec_06_nt\&nn.php.

Whorf, B. L. (1956). Language, Thought, and Reality: Selected Writings of Benjamin Lee Whorf. Ed. John B. Carroll. Cambridge, MA: MIT Press.

Wierzbicka, A. (1997). Understanding cultures through their Key Words. New York: Oxford University Press. 